\title{
Undergraduates' awareness, use and satisfaction with online public access catalogue (OPAC) of Benue State University Library, Makurdi, Nigeria
}

\author{
Comfort Member Tyopev \\ Information Literacy Unit \\ Benue State University Library, Marurdi, Nigeria \\ E-mail: cmtyopev669@gmail.com \\ Cell: +2347031099187 \\ Murpy Tersoo Igbudu \\ Virtual Library, Benue State University Library, Marurdi, Nigeria \\ E-mail: murphyigbudu@gmail.com \\ Cell: +2348038434748
}

Akuhwa Ver

Virtual Library

Benue State University Library, Marurdi, Nigeria

E-mail: akuhwaver79@gmail.com

\begin{abstract}
The purpose of this paper was to determine the extent to which undergraduates at Benue State University are aware of the OPAC, the extent of usage, the level of satisfaction derived from the usage and challenges encountered in the use of OPAC in the university library. The study was guided by four specific objectives and four research questions. Descriptive survey research design was adopted for the study. The population consisted of 9,864 undergraduate who registered with the library during 2017/2018 academic session. The sample size was 384 undergraduate students. Data was collected through a self-structured questionnaire. The data collected were analysed using frequency, percentages, mean and standard deviation. The findings revealed that most of the respondents $-232(60.4 \%)$-were not aware of OPAC services, only $152(39.6 \%)$ respondents indicated their awareness of OPAC in retrieving needed library materials. The study also showed that the extent of OPAC use by undergraduates was to a low extent and the students were dissatisfied with OPAC services; that the undergraduates encountered several challenges which led to the low usage and dissatisfaction with the OPAC of the Benue State University Library. The study concluded that the creation of the OPAC was to facilitate retrieving information resources that had been acquired and organised by the university library. However, poor awareness, improper orientation/training of students among others have posed great challenge for its effective usage. The study therefore recommended that all the identified challenges be tackled by the university library management in order to enhance OPAC usage by the students.
\end{abstract}

Keywords: Online public access catalogue (OPAC), Undergraduates, Benue State University Library, Makurdi, Nigeria

\section{Introduction}

The main aim of a university library is to provide information resources and services to support in teaching, learning, research and community service. No university can be successful without a library especially as accreditation of the university academic programmes depends on the provision of adequate information resources and services to support the programmes in the university library. In providing these resources, trained personnel called librarians are employed in the university library to organize and provide the available information resources and assist library users in retrieval and use of the resources. For easy accessibility and usage, the library provides its users with information retrieval tools such as the card catalogues and index cards through which the library collections could be accessed (Arua, Uzuegbu \& Ugah, 2014).

With the introduction of ICT in libraries, most university libraries now automate their library operations and services which led to the conversion of library catalogue to online public access catalogue (OPAC) to enhance easy and remote access to 
Tyopev Comfort Member, Igbudu Murpy Tersoo and Akuhwa Ver: Undergraduates' awareness, use and satisfaction with the online public access (OPAC) of Benue State University Library, Markurdi, Nigeria.

library information resources. OPAC is a computerised version of the library catalogue that acts as an information retrieval system for the library user. Thanuskodi (2012) defined OPAC as an information retrieval system characterised by short bibliographic records, mainly for books, journals and audiovisual materials available in a particular library. Gohain and Saikia (2013) defined OPAC as one of the information and communication technology (ICT) tools that provide access to any of the information contained in the records describing the holding of a library that allows users to search document by authors, titles, subject and keywords from terminal as well as allows printing, downloading or exporting of records via e-mails etc. Bamidele, Omeluzor, Onoyeyan and Aluko-Arowolo (2014) posited that OPAC is an information retrieval system that helps library users to filter through a pool of information sources, so that only those documents that are relevant to their information needs are actually retrieved.

The basic purpose of the OPAC is to create a database of library collections which provides an online catalogue to help users in identifying and searching resources. The advantages of OPAC services are numerous as it saves user's time, ease of use, allows multiple access, links to other information resources, can be access remotely and available 24/7. The status of any book may be known as Check Out, Item Available for Loan, Not for Loan, No. of copies are available for loan, Reserve/reference items, current location are displayed for users to know the actual status of a book. Users can easily know the activities with the library by logging unto their account on OPAC. This is why Mulla and Chandrashekara (2009) emphasized that OPAC has made the library collections, easily accessible to everyone by breaking the physical boundaries of the library. Emiri (2015) agreed that the ability to locate a resource and reference materials without stress makes the OPAC a tool of importance in the library.

The Benue State University (BSU) Library which took off in 1992. In 1993, the initial book stock was only fifty (50) books received as donations to kick start the operations of the university library (Ugbagir, 2016). The library collection at present is above 60,000 volumes in various fields of study to support teaching, learning and research in the areas of arts, education, environmental science, law, management science, medicine, social sciences and sciences. The university library has seven faculty/departmental libraries in addition to the main library which housed most of the resources. The library has partially automated its services using Koha Integrated Library Management Software. With this software, the BSU Library has converted its bibliographic records into computer format using Koha software to create an OPAC. The creation of OPAC is not intended to eliminate the use of the card catalogues but to complement it to ease the problem of information retrieval by library users. The library users are now expected to use OPAC to search library holdings, request articles, place holds, make recent comments on articles and purchase suggestions.

In Benue State University Library, computers are placed opposite the circulation desk for OPAC search. It is expected that undergraduate students with access to the internet whether at homes, offices, hostels or lecture rooms will access library collections before coming to the library to read or borrow their needed information materials. It is worthy to note also that the efficient use of the OPAC by undergraduate students may depend on some variables such as awareness of OPAC services, skills competency and their satisfaction with the OPAC services. It was based on this that the researchers sought to determine the extent to which undergraduate students are aware of the OPAC services, the extent of usage and their satisfaction with the OPAC services in Benue State University Library, Makurdi, Nigeria.

\section{Statement of the problem}

Accessibility of information resources by library users has been a major concern in 
Tyopev Comfort Member, Igbudu Murpy Tersoo and Akuhwa Ver: Undergraduates' awareness, use and satisfaction with the online public access (OPAC) of Benue State University Library, Markurdi, Nigeria.

libraries. In order to address the problems of information searching and retrieving, libraries have adopted the creation of OPAC services. OPAC as a quick and accurate tool for information retrieval has many advantages over the manual catalogues such as multiple accesses to library users, saves time, has no geographical boundary, availability of service 24/7 and can link the user with other library information resources and services. Undergraduate students who constitute the major population of the library users are expected to use the OPAC to retrieve needed library materials fast and accurately for their academic purposes.

However, the researchers have observed that there is low usage of the OPAC services by library users especially undergraduate students in Benue State University Library. What could be responsible for the low usage? This observation motivated the researchers to determine the undergraduates' awareness, use and satisfaction with the OPAC of Benue State University Library (BSU), Makurdi, Nigeria.

\section{Research questions}

The following research questions were answered in the study:

1. To what extent are undergraduates aware of the OPAC of BSU Library?

2. To what extent do undergraduates use the OPAC sof BSU Library?

3. What is the students' level of satisfaction with the use of the OPAC of BSU Library?

4. What are the challenges encountered by undergraduates in the use of the OPAC of BSU Library?

\section{Literature review}

The library OPAC was developed as a tool to locate those information resources that had been acquired and organised by the library. Most libraries have converted a vast number of bibliographic records into computer format using the Machine-Readable Cataloguing (MARC) format. According to Umar, Abareh and Basaka (2017), the trend worldwide has proved that information provision and delivery had shifted the traditional models to electronic and web-based formats hence the creation of the OPAC in libraries. OPAC provides the facilities to library users to search different types of information resources using strategies like simple search, Boolean search and advanced search of document more quickly and easily than when searching for documents manually.

OPAC awareness can be described as a state of being knowledgeable about availability of OPAC in a university library. In the view of Fati and Adetimirin (2015), awareness of OPAC is the degree of user's knowledge and availability of the services and the extent to which users make use of them. The awareness of OPAC services includes users' knowledge of its existence and the purpose it serves. According to Ruzegea (2012), awareness of OPAC is an important first step towards access and eventually increased usage of library materials and other relevant information in library and outside libraries or online databases to aid researchers and students in their learning process. It is in this regard also that, Kwafoa, Imoro and Afful-Arthur (2014) averred that availability of information resources and services does not transits to usage by library users as it depends largely on the extent to which they are aware and the satisfaction they derived from its usage.

Bamidele, Omeluzor, Onoyeyan and Aluko-Arowolo (2014) established in their study of OPAC use by faculty members of Babcock University, Nigeria that despite its acclaimed usefulness of OPAC, most faculty members tend to prefer traditional methods to OPAC. The study also revealed that majority of them $(71.4 \%)$ were not aware that OPAC can be used to retrieve materials before coming to the library to read or borrow the materials while $(59.2 \%)$ were not aware that the materials available in the library can be accessed outside the library building. The study identified lack of orientation of OPAC in the library hinders awareness and use of OPAC in the study. The study therefore 
Tyopev Comfort Member, Igbudu Murpy Tersoo and Akuhwa Ver: Undergraduates' awareness, use and satisfaction with the online public access (OPAC) of Benue State University Library, Markurdi, Nigeria.

recommends that librarians should organize orientation and sensitization programmes in order to create awareness, and encourage the university community and especially faculty members at various schools to effectively use OPAC to ensure maximum utilization of library information resources. In similar view, Ebiwolate (2010) study on the use of library catalogue by undergraduate students in the Niger Delta university library revealed that majority of the students were not aware of library catalogue as a result they had never used the catalogue.

In his study on awareness and use of OPAC among distance learners of the Open University of Tanzania, Msagati (2016)revealed that most of the respondents (75.22\%) were not aware of OPAC and thus only few respondents $(22.61 \%)$ used OPAC to retrieve library materials. Similarly, Umar, Abareh and Basaka (2017) study shows that only $(26.7 \%)$ respondents were aware of public access catalogue while $(64.1 \%)$ were not aware which led to low utilization of the public access catalogue by undergraduate students of Abubakar Tafawa Balewa university Bauchi. Contrary, Fabunnmi and Asubiojo (2013) investigated the awareness and use of Online Public Access Catalogue (OPAC) by students of Obafemi Awolowo University, Nigeria. The study revealed that $68.7 \%$ of the respondents were aware of the OPAC services however, the students who were aware of the library OPAC and did not use it to access library resources were statistically significant. The low usage could be attributed to other factors such as lack of orientation/training, retrieval skills and internet connectivity among others could also hinders effective usage.

On the extent of the OPAC use by undergraduates, Fati and Adetimirin(2015) reported in their study that undergraduates' extent of OPAC use in both OAU and UNILAS was very low as majority of the students did not make use of their library OPAC at all. Similarly, Adedibu (2008) examined catalogue use by science students of the University of Ilorin and the results showed that the users of OPAC represented a small portion with $(7.9 \%)$. The study identified inadequate knowledge of how to use OPAC which in the context may refers to lack of awareness and retrieval skills. In their studies on the use of OPAC by the users, Rajput, Naidu and Jadon (2008) revealed that the tool is useful and at the same time respondents felt that there must be someone near the OPAC to help in retrieving the required documents. This means there should be staff around OPAC vicinity to render assistance to those having difficulty in retrieving documents. In their study, Kumar and Mahajan (2015) revealed that OPAC usage in public libraries revealed that there is lack of computer skill and awareness on the part of users, lack of proper orientation and cooperation from the library staff. Although, the users said they were satisfied with the OPAC and its services.

On the level of satisfaction with library service, Au, Ngai and Cheng (2008) as cited in Olaojo, Gbenga, Adebayo \&Ayoola (2018) defined users' satisfaction as the affective and cognitive evaluation the user develops from a pleasant experience using a product or service. This could mean the psychological state of mind of a user about the information system performance which leads to the level of satisfaction or dissatisfaction with what its offers. User satisfaction with library services help the library to measures the overall performance of the information system its offer to library users. In this context, the product or service offers by the library is the OPAC.

The study of Shorunke, Eluwole and Gbenu (2014) carried out an evaluation study on users' satisfaction with Landmark University's online public access catalogue revealed that $97 \%$ of the undergraduates were highly satisfied with the performance of the OPAC services. However, the respondents indicated two major challenges to OPAC exploitation, which were inadequate ICT infrastructure and lack of remote access to the OPAC. Contrary, the study carried out by Kumar and Vohra (2011) to investigate the use of OPAC by the users at Guru Nanak Dev 
Tyopev Comfort Member, Igbudu Murpy Tersoo and Akuhwa Ver: Undergraduates' awareness, use and satisfaction with the online public access (OPAC) of Benue State University Library, Markurdi, Nigeria.

University Library, Amritsar (Punjab) revealed that most of the respondents use the OPAC to locate documents despite facing some difficulties. They were however not satisfied with the OPAC services. The study suggests that the users should be made to familiar with the use and operation of the OPAC by providing special training.

Mulla and Chandrashekara (2009) carried out a study to determine the effective use of online public access catalogue (OPAC) at the libraries of engineering colleges in Karnataka. The study identified some of the major constraints for the use of OPAC at the libraries of engineering colleges to include lack of awareness of user community, OPAC is not user friendly software and lack of information technology (IT) competency. The study highlighted the need for an education programme module for users to promote the effective usage of OPAC. An attempt is made through this study to present the difficulties faced by users at engineering college libraries, in searching information using OPAC.

\section{Methods}

The study adopted a descriptive survey research design. The area of the study was Benue State University Library, Makurdi,
Nigeria. The population for this study comprised of 9,864 undergraduate students who registered with the library during 2017/2018 academic session. The sample size of the study was 384 which was determined using Taro Yamane Formula. Data were collected through self-structured questionnaire. The data collected were analysed using frequency, percentages, mean and standard deviation to answer the research questions. For research question one, a benchmark of $50 \%$ was considered as 'Aware' while those below were considered 'Not Aware'. For research questions $2-4$,benchmark of a mean value of 2.50 was considered 'High Extent/Satisfied/Agreed' while those below 2.50 were considered 'Low Extent/Dissatisfied/Disagreed'.

\section{Results and discussion}

This section is presented according to the research questions.

Research question one: To what extent are the undergraduates aware of the OPAC of BSU Library?

The data in Table 1 are used to answer this question. 
Tyopev Comfort Member, Igbudu Murpy Tersoo and Akuhwa Ver: Undergraduates' awareness, use and satisfaction with the online public access (OPAC) of Benue State University Library, Markurdi, Nigeria.

Table 1: Frequency counts and percentages of awareness of the OPAC of BSU Library by undergraduate students

\begin{tabular}{|c|c|c|c|c|c|}
\hline \multirow[b]{2}{*}{ Awareness of OPAC services } & \multicolumn{2}{|c|}{ Frequency } & \multicolumn{2}{|c|}{ Percentage $(\%)$} & \multirow[b]{2}{*}{ Decision } \\
\hline & Aware & $\begin{array}{l}\text { Not } \\
\text { Aware }\end{array}$ & Aware & $\begin{array}{l}\text { Not } \\
\text { Aware }\end{array}$ & \\
\hline $\begin{array}{l}\text { Are you aware of online public access catalogue } \\
\text { (OPAC) services at BSU Library? }\end{array}$ & 152 & 232 & 39.6 & 60.4 & Not Aware \\
\hline $\begin{array}{l}\text { Are you aware that OPAC is a useful information } \\
\text { retrieval tool that tells the presence or absence of } \\
\text { information materials in the library? }\end{array}$ & 214 & 170 & 55.6 & 44.4 & Aware \\
\hline $\begin{array}{l}\text { Are you aware that you can access OPAC outside } \\
\text { the library building i.e. hostel, lecture halls or at } \\
\text { home? }\end{array}$ & 139 & 245 & 36.2 & 63.8 & Not Aware \\
\hline $\begin{array}{l}\text { Are you are that you can retrieve details of a } \\
\text { book/journal before coming to the library? }\end{array}$ & 122 & 262 & 31.8 & 68.2 & Not Aware \\
\hline $\begin{array}{l}\text { Are you aware that OPAC is accessible through } \\
\text { computer terminals/mobile devices? }\end{array}$ & 229 & 155 & 59.6 & 40.4 & Aware \\
\hline Are you aware that OPAC is accessible $24 / 7 ?$ & 125 & 259 & 32.6 & 67.4 & Not Aware \\
\hline $\begin{array}{l}\text { Are you aware that OPAC interface can link you } \\
\text { to subscribed databases, online reference services } \\
\text { and other vital information? }\end{array}$ & 140 & 244 & 36.5 & 63.5 & Not Aware \\
\hline
\end{tabular}

The data in Table 1 reveal that there is poor awareness of the OPAC services among undergraduate of Benue State University Library. A majority of the respondents indicated that they are not aware of the OPAC. Item 1 has $152(39.6 \%)$ aware and 232(60.4\%) not aware; item 2 has 214(55.6\%) aware and 170(44.4\%) not aware; item 3 has 139(36.2\%) aware and 245(63.8\%) not aware; item 4 has $122(31.8 \%)$ aware and 262(68.2\%) not aware; item 5 has $229(59.6 \%)$ aware and 155 $(40.4 \%)$ not aware; item 6 has $125(32.6 \%)$ aware and 259(67.4\%) not aware and item 7 has $140(36.5 \%)$ aware and 244(63.5\%) not aware. On the whole 2 of the items (items 2 and 5) with percentages above 50\% were accepted as those who are aware of the OPAC services while the other 5 items were regarded as those who are 'not aware' of the OPAC services with percentages below $50 \%$. This implies that majority of undergraduate students are not aware of the existence of OPAC in the university library. This study agrees with previous studies such as Bamidele, Omeluzor, Onoyeyan and Titilayo (2014), Ebiwolate (2010), Msagati (2016), Umar, Abareh and Basaka (2017) who reported in their studies that majority of the respondents were not aware of the creation of OPAC services in their university libraries. This could be the reason whyRuzegea (2012) opined that awareness of OPAC is an important first step towards access and eventually increased usage of library materials and other relevant information in library and outside libraries or online databases to aid researchers and students in their learning process. For OPAC to be used effectively, the library have carryout programmes that will create awareness, proper orientation/training of library users on how to use OPAC as a vital information retrieval tool. 
Tyopev Comfort Member, Igbudu Murpy Tersoo and Akuhwa Ver: Undergraduates' awareness, use and satisfaction with the online public access (OPAC) of Benue State University Library, Markurdi, Nigeria.

Research question 2: To what extent do the undergraduates use the OPAC of BSU

Library?
The data in Table 2 are used to answer this question.

Table 2: Mean and standard deviation of the extent to which the undergraduates use the OPAC of BSU Library?

\begin{tabular}{lccc}
\hline \multicolumn{1}{c}{ Extent of OPAC use } & Mean & Std. Dev & Decision \\
\hline I use OPAC to retrieve reading materials from the library shelves & 2.27 & 1.08 & Low Extent \\
$\begin{array}{l}\text { I use OPAC to check if the needed materials are in the library } \\
\text { before coming to the library }\end{array}$ & 2.23 & 1.08 & Low Extent \\
I use OPAC to reserved/borrow books from the library & 2.06 & 1.04 & Low Extent \\
$\begin{array}{l}\text { I use OPAC interface to link to other information resources in } \\
\text { the library }\end{array}$ & 2.10 & 1.06 & Low Extent \\
I use OPAC to check my status with the library & 2.07 & 1.06 & Low Extent \\
Grand Mean & $\mathbf{2 . 1 5}$ & $\mathbf{1 . 0 7}$ & Low Extent \\
\hline
\end{tabular}

Table 2 shows the extent to which undergraduate students in BSU use the OPAC to access information resources in the university library. The findings revealed that there is low usage of OPAC by the students as the grand mean of all the items was only 2.15 which is below the benchmark of 2.50. This implies that the undergraduate students in BSU to a low extent use OPAC in searching and retrieving information resources in the university library. The finding agreed with that of Fati and Adetimiri (2015), Adedibu (2008) which revealed that there is low usage of OPAC among undergraduate students in university libraries. The low usage of the OPAC could be attributed to lack of awareness, lack of proper orientation/training given to students on how to use the OPAC or inadequate retrieval skills possessed by the students among other hindrance.

Research question 3: What is the students' level of satisfaction with the use of the OPAC of BSU Library?

The data in Table 3 are used to answer this question. 
Tyopev Comfort Member, Igbudu Murpy Tersoo and Akuhwa Ver: Undergraduates' awareness, use and satisfaction with the online public access (OPAC) of Benue State University Library, Markurdi, Nigeria.

Table 3: Mean and Standard Deviation of the students' level of satisfaction with the use of OPAC in BSU Library

\section{Satisfaction with the use of OPAC $\quad$ Mean $\quad$ Std. Dev Decision}

I am satisfy with the ease of navigation

$2.43 \quad 1.01 \quad$ Dissatisfied

$\begin{array}{lll}2.64 & .89 & \text { Satisfied }\end{array}$

I am satisfy with the accessibility of library materials

I am satisfy with the computer terminals available for

$2.34 \quad 1.04 \quad$ Dissatisfied

accessing OPAC

I am satisfy with the information materials uploaded on OPAC

$2.43 \quad 1.01 \quad$ Dissatisfied

I am satisfy with the assistance given to me by library staff

$2.21 \quad 1.10 \quad$ Dissatisfied

I am satisfy with the with ease of access to the actual

$2.55 \quad .93 \quad$ Satisfied

information material retrieved

I am satisfy with the OPAC interface

$2.35 \quad 1.05 \quad$ Dissatisfied

Grand Mean

$2.42 \quad 1.00 \quad$ Dissatisfied

Table 3 shows overall satisfaction level of undergraduate students in using the OPAC of BSU Library. It highlights only two items (2 and 5) with mean score of 2.64 and 2.55 which are above the benchmark of 2.50 agreed by undergraduate students as those features of the BSU Library OPAC to a high extent. Others (items 1,3,4,6 and 7) with mean scores ranging from $2.21-2.43$ which are less than 2.50 are satisfied with the OPAC to a low extent. This implies that majority of the undergraduate students are dissatisfied with the OPAC of Benue State University Library. The dissatisfaction with the OPAC by undergraduate students could be as a result of lack of awareness, proper orientation/training on how to use the OPAC to search and retrieve library materials among other challenges faced by undergraduate students has led to low usage and satisfaction. The finding agrees with that Kumar and Vohra (2011) but disagrees with Shorunke, Eluwole and Gben (2014) whom study showed that $97 \%$ level of satisfaction by respondents with the OPAC service. The high level of satisfaction may be as a result of their awareness of OPAC features, proper orientation/training organised for the students, possession of ICT skills as well as other factors that aid usage.

Research question 4: What are the challenges encountered by the undergraduates in the use of the OPAC of BSU Library?

The data in Table 4 are used to answer this question. 
Tyopev Comfort Member, Igbudu Murpy Tersoo and Akuhwa Ver: Undergraduates' awareness, use and satisfaction with the online public access (OPAC) of Benue State University Library, Markurdi, Nigeria.

Table 4: Mean and Standard Deviation of the challenges encountered by the undergraduates in the use OPAC in BSU Library

\begin{tabular}{llll}
\hline Challenges encountered with OPAC use & Mean & Std. Dev & Decision \\
\hline Lack of awareness of OPAC & 3.30 & .78 & Challenge \\
Lack of orientation/training by library staff & 3.29 & 1.08 & $\begin{array}{l}\text { Challenge } \\
\text { Challenge }\end{array}$ \\
OPAC interface is not user friendly & 3.23 & 1.09 & \\
& & & \\
& 3.26 & 1.09 & Challenge \\
Lack of ICT skills by users & 3.23 & 1.10 & Challenge \\
I can't find some titles on OPAC although they are & & & \\
on the shelves & & & \\
& 2.21 & 1.08 & Not challenge \\
Inadequate computer terminals & & & \\
& 3.26 & 1.10 & Challenge \\
Poor network connectivity & 3.11 & 1.18 & Challenge \\
Irregular power supply & & & \\
\hline
\end{tabular}

Table 4 shows the challenges encountered by undergraduate students in the use of the OPAC in BSU Library. The findings show that all the items except one were agreed by the students as challenges hindering their effective use of the OPAC of BSU Library. This shows that the creation of OPAC and the provision of computer terminals alone cannot enhance usage but proper awareness about OPAC and the purpose it serves as well as proper orientation/training of users on how to locate and retrieve documents can in a great extent enhances usage. Most of the challenges identified in this study agrees with the previous studies such as Thanuskodi (2012), Bamidele, Omeluzor, Onoyeyan and Titilayo (2014), Mulla and Chandrashekara (2009) and Kumar and Mahajan (2015). It is evident from the study that lack of awareness of the OPAC services proper orientation/training by the library staff, poor ICT skills possessed by the students are the major hindrance of the effective use of OPAC by undergraduate students in BSU library. The study also agrees with Ruzegea (2012)who opined that awareness of OPAC is an important first step towards access and actual usage of library materials and other relevant information resources in the library and outside libraries or online databases to aid researchers and students in their learning process. Since the students are not aware of OPAC services, their perception of it may be negative even if other variables may be in place.

\section{Conclusion}

The creation of OPAC is increasingly and emerging as one of the most valuable information retrieval tools for accessibility and utilization of information resources in university libraries. The major reason for OPAC use by undergraduate students is because it minimizes the time and stress of searching through for library materials. However, effective use of OPAC depends on factors such as its awareness, proper orientation/training of library users on how to conduct searches, possession of ICT skills by users, constant internet connectivity, provision of alternative power supply to complement the public supply among other variables significantly influence usage.

The findings of this study showed that awareness, use and users' satisfaction with the OPAC by undergraduate students of Benue State University is low because a majority of the respondents are not aware of the OPAC service in the university library. It is also evident that apart from lack of awareness, proper orientation/training on the use of OPAC is a crucial factor as well as lack of search skills by the students. This invariably shows that the university library did not carry out proper user education programme to enlighten the library users about new services in the 
Tyopev Comfort Member, Igbudu Murpy Tersoo and Akuhwa Ver: Undergraduates' awareness, use and satisfaction with the online public access (OPAC) of Benue State University Library, Markurdi, Nigeria.

library such as the OPAC that has been created and the advantages it offers so as to enhance usage.

The main purpose for the creation of the OPAC in the university libraries is to enhance information retrieval processes and wider access to library materials and usage among the university community. This purpose cannot be achieved if the awareness of the OPAC and by extension proper orientation/training is not given to those it is meant for. The following recommendations are made based on the results of the study:

1. University libraries should carry out awareness programmes such as sensitization of students and faculties on the presence of OPAC in their libraries. The students should be advised to register online with the circulation unit to enable them use the service.

2. University libraries should organise proper orientation/training for undergraduates on how to use of the OPAC in retrieving their needed information. This can be achieved if the library schedules a timetable for the training, department by department to avoid overcrowding.

3. The university libraries should arrange the feedback system through suggestions/complaints boxes for library users to know areas that need improvement.

4. University libraries should make sure that there is always library staff in the vicinity of OPAC computer terminals to assist students in retrieving the required documents.

5. University libraries should furthermore, provide alternative power supply to supplement the public power supply and increase the internet connectivity.

\section{References}

Adedibu, L.O. (2008). Catalogue use by science students in the University of IIorin, .Libri, 58, 58-62
Arua, U., Uzuegbu, A.D. \& Ugah, A.D. (2014).Information literacy education for tertiaryinstitutions, Umuahia, Nigeria: Zeh Communications

Bamidele, I.A., Omeluzor, S.U., Onoyeyan, G. \&Aluko-Arowolo, T. K. (2014). Faculty members' awareness and use of online public access catalogue (OPAC) services at Babcock University, Nigeria: A study. Journal of Information \& Knowledge Management, 4(11): 29-37. https://www.researchgate.net/p ublication/269011225.

Ebiwolate, P.B. (2010). Use of the library catalogue by undergraduate students in Niger Delta University Library. Library Philosophy and Practice (ejournal). Retrieved from http://www. digitalcommons.unl.edu/libphilpract/3 92.

Emiri, O. (2015). Influence of demographic factors $n$ use of OPAC by undergraduate in selected university libraries in Southern Nigeria. International Journal of Scientific and Technology Research, 4(7), 164169

Fabunmi, O.M. \& Asubiojo, B.O. (2013). Awareness and use of online public access catalogue by students of Obafemi Awolowo University, IleIfe, Nigeria. https://www.resear ch gate.net/publication/280048705.

Fati, O.I \& Adetimirin, A. (2015). OPAC awareness as a factor affecting opac use by undergraduates in two nigerian libraries. International Journal of Academic Library and Information Science. 3(3), 72-80

Gohain, A. \& Saikia, M. (2013). Use and users satisfaction on online public access catalogue (OPAC) services among B.Tech. Students of School of Engineering in Tezpur University: A Survey. Library Philosophy and Practice (e-journal). Retrieved from 
Tyopev Comfort Member, Igbudu Murpy Tersoo and Akuhwa Ver: Undergraduates' awareness, use and satisfaction with the online public access (OPAC) of Benue State University Library, Markurdi, Nigeria.

https://digitalcommons.unl.edu.libphil prac/990.

Kumar, P. \&Mahajan, P. (2015).Use and ssage of OPAC in public libraries in Chandigarh City (India): A Study. https: //www.researchgate.net/scien tific-contributions/.

Kumar, S. \& Vohra, R. (2011). Use of online public access catalogue in Guru Nanak Dev University library, Amritsar: a study. SRELS Journal of Information Management, 48 (5):51928.

Kwafoa, P.N.Y., Imoro, O. \& Afful-Arthur, P. (2014).Assessment of the use of electronic resources among administrators and faculty in the University of Cape Coast .Library Philosophy and Practice (e-journal).

Msagati, N. (2016). Awareness and use of OPAC by distance learners: The case of the Open University of Tanzania. Library Philosophy and practice (Ejournal). Retrieved from http://digitasl commons.unl.edu.1482

Mulla, K. R. \& Chandrashekara, M. (2009). Access of web-OPAC in engineering college libraries in Karnataka: A survey. SRELS Journal of Information Management, 46(3): 321-32.

Olaojo, P.O., Gbenga, F.A., Adebayo, R.T. \& Ayoola, T.J. (2018).Students' Perception and Satisfaction with Use of E-Library Services in Academic Libraries in Oyo State, Nigeria.Ebonyi Journal of Library and Information Science, 5(1): 237254
Rajput, P.S., Naidu, G.H.S. \& Jadon, G.S. (2008). Use of online public access catalogue in Devi Ahilya University Library, Indore. SRELS Journal of International Management 45(1), 5562.

Shorunke, O.A., Eluwole, O.A. \& Gbenu, S.A. (2014). Evaluating users' satisfaction with Landmark University's online public access catalogue, Samaru Journal of Information Studies, 14(1 \&2)

Thanuskodi, S. (2012). Use of online public access catalogue at Annamalai University Library", International Journal of Information Science, 2(6): $70-74$.

Doi:10.5923/j.ijis.20120206.01.

Ugbagir, N.N. (2016). assessment of use of faculty libraries resources by undergraduate students in Benue State University Library Makurdi, Nigeria. Humanities and Social Sciences, 4 (6): 166-172. Doi: 10.11648/j.hss.20160406.16

Umar, F. B., Abareh, H. M. \& Basaka, A. B. (2017). Awareness and utilization of library public access catalogue by undergraduate students of Abubakar Tafawa Balewa University (ATBU) Bauchi, Bauchi State of Nigeria. International Journal of Research in Library Science, 3(1), $131-138$. 